\author{
大腿ヘルニア症例の検討 \\ 国保久美浜病院外科 \\ 吉井一博里輝幸赤木重典
}

1987年 4 月から1999年 3 月までに当科で経験した大腿へルニア症例30例を対象とし，

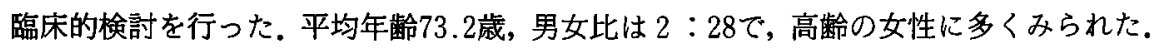
主訴は鼠径部膨隆など局所症状 23 例, イレウス症状 4 例, 他症状 3 例であった. 部位は 右側18例, 左側10例, 両側 2 例であった. 診断は全て身体所見によりなされた. 他症状 例, 両側例の片側は受診時に鼠径部の触診により診断された. 嵌頓は 5 例 (16.7\%) 飞 認め, 緊急手術もこの 5 例に施行された. うち 2 例に腸管壊死を認め, この 2 例に腸切 除併施を要した. 腸切除例の 1 例に創感染の術後合併症を認め, 創治痖が遷延した. 嵌 頓症例は非嵌頓例より術後在院日数が長かった。大腿へルニアは高齢の女性に多く, 日 常診察で注意を払うことによって，嵌頓を防ぐ努力をすべきである。

索引用語：大艆へルニア, 診断, 嵌頓率

緒言

当院での大腿へルニア症例について検討したので報 告する.

\section{対 象}

対象は1987年 4 月から1999年 3 月まで過去 12 年間に 当院で経験した大腿へルニア症例30例で，これは同期 間に経験した成人鶃径部へルニア症例137例の $21.9 \%$ にあたつた。

\section{結 果}

\section{1. 年齢, 性別}

30症例の年齢分布を示す(図 1).52歳〜92歳で70歳

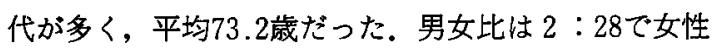
に压倒的に多かった，女性症例について出産歷がわか つた26例についてみると出産数 0 は皆無で，2人〜7 人まで平均 3.54 人だった(図 2 )。 また, 入院時に職業 のわかった女性症例23例についてみると農業に従事し ていた人が12例と約半数を占めた（図 3 ).

\section{2. 症状, 診断, 部位}

受診時の主訴についてみると鼠径部膨隆19例, それ に鼠径部疼痛を伴ったもの 4 例, 腸閉塞症状を伴った ものが 4 例で, この 4 例と鼠径部痛を訴えた 1 例が嵌 頓症例であった，その他，腹痛や腰痛を訴えて受診, 診察時に鼠径部も触診し, 診断されたものが 3 例あっ

1999 年 8 月 20 日受付 2000 年 3 月21日採用
た(図 4).

診断は全て視・触診など身体所見によりなされた。 ヘルニア内容が還納されていても還納されない腹膜前! 脂肪織を腫瘤状に触知し, 診断することができた。最 近の 3 症例ではリンパ節などとの鑑別に体表エコーを 用いて診断の参考にしている.

部位は右側18例, 左側10例, 両側 2 例であった（図 5 ). 両側例は他院で 1 年前に左大腿へルニア嵌頓にて 手術を受けていた症例と当院を左大腿へルニア嵌頓症 状で受診時に触診で対側にも大腿へルニアを認めた症 例であった。

嵌頓症例は 30 例中 5 例，16.7\%だった。 また, 術前

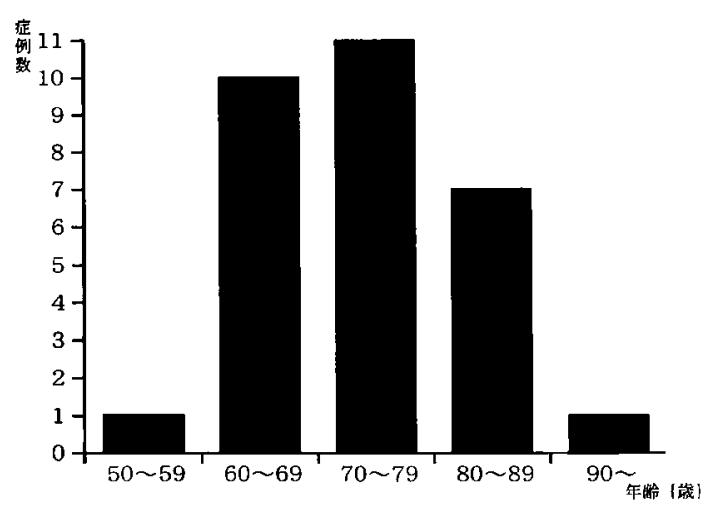

図 1 大煺ヘルニア症例年齢分布 
診断で臼径へルニアと診断したものが 2 例 (6.7\%) あ った.うち 1 例は鼠径へルニア合併症例だった。

\section{3. 術前合併症}

術前合併症としては高血圧症 ( 9 例- $-30 \%$ ), 骨粗鬆 症 (7 例- $23 \%)$ など, 高齢者にみられるものが多か った．鼠径へルニアの手術既往のあったものは 2 例 （6.7\%）だった（表 1 ).

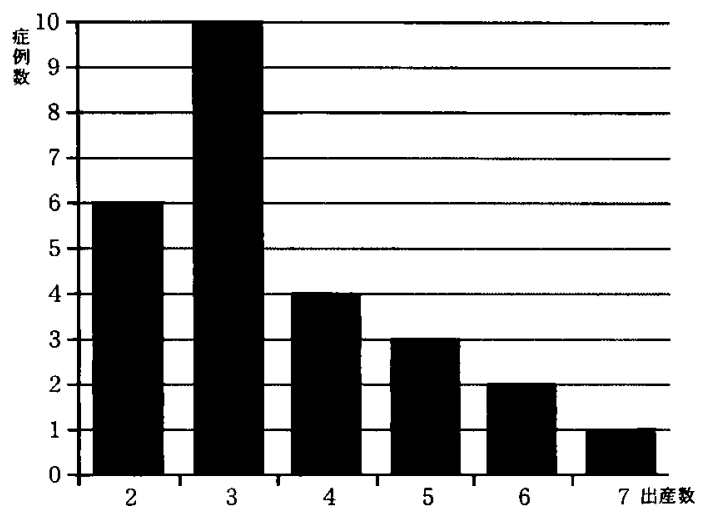

図 2 大腿へルニア女性症例出産数

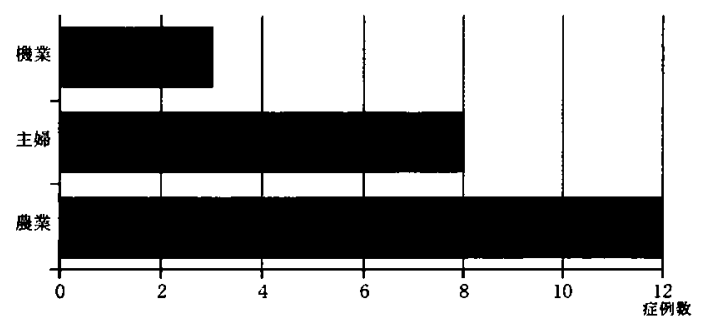

図 3 大腿ヘルニア女性症例瞕業

\section{4. 手術術式, 崱頓内容}

術式については McVay 法が25例と多く，このうち 2 例は腸切除を伴った. その他, Moschcowitz 法, Moschcowitz+Ilio-pubic tract repair がそれぞ 2 例, 最近の 2 例は Mesh-plug 法で行った（図6)。へ ルニア内容は非嵌頓例ではなしが21例, 大網が 5 例, 嵌頓例では小腸が 4 例，小腸十大網が 1 例だった（表

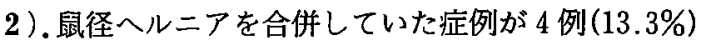
あった。

\section{5. 術後合併症}

術後合併症は非嵌頓例25例で seroma 2 例 ( $8 \%$ ), 大腿腫脹 1 例, 腰麻後頭痛 1 例を認めた（表 3 ）が, いずれも軽度で, seroma は数回の穿刺排液で, 他は自 然に軽快した。嵌頓例 5 例中, 創感染を 1 例に認め, 創治瘾が要延した，全例無事退院した。

\section{6. 嵌頓症例}

嵌頓症例 5 例の一覧を示す (表 4). 平均年齢79.4歳, 全例女性で，腸閉塞症状を呈さなかったのは 1 例で, この 1 例は Richter 型ヘルニアであった，腸切除を併 施したものが 2 例あった. 嵌頓症例は手術時間, 術後 在院日数ともに非嵌頓例より長くかかる傾向にあった (表 5 ).

\section{考 察}

大腿ヘルニアは本邦の報告では高齢の女性に多いと されているが, 当院における検討でも平均年齢73.2歳, 男女比 $2: 28$ と高齢女性に多かった．文献的には棚瀬 らは62.5歳 ${ }^{1)}$, 田中らは64.8歳2) と平均年齢60歳代, 男 女比 $1: 4.5 \sim 8^{3) \sim 5)}$ とされているが，当院ではより高 齢，より女性に多かった。また，大腿へルニアの頻度 については成人鼠径部へルニアの $5.2 \sim 8.2 \%^{3) \text { ) }}$ と報

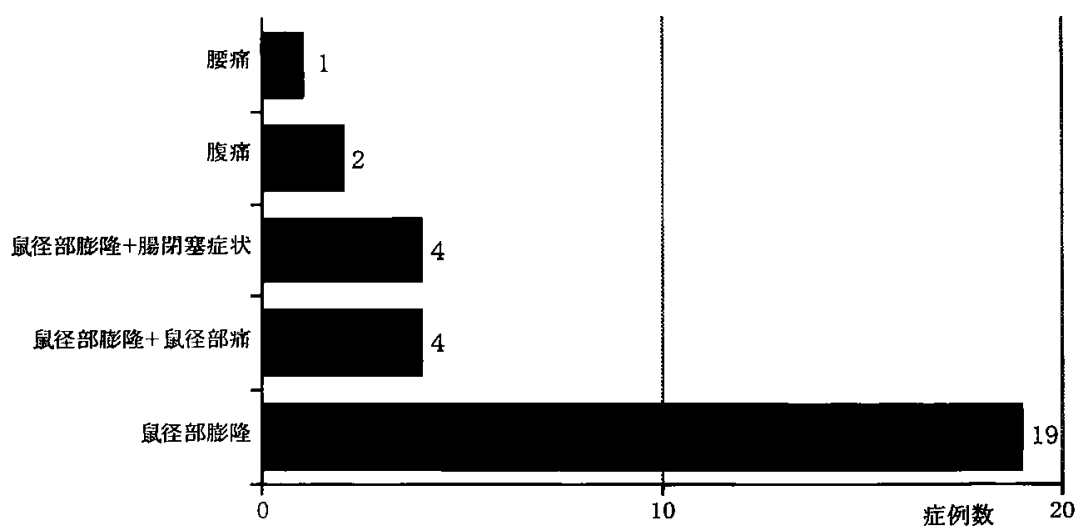

図 4 大腿ヘルニア症例受診時主訴 
告されているが, 当院では $21.9 \%$ あり，高齢女性が 多い地域特性も影響しているのだろうが，大眼へル二 アではヘルニア内容還納時でも還納されない腹膜前脂

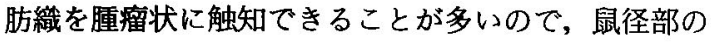
触診を注意梁く行い病変をみつける努力をしている成 果とも考えている．大腿へルニアは嵌頓を起こしやす いとされ, 21.7 79\% ${ }^{1224) ~ 8)}$ の嵌頓率とされているが, 当院での嵌頓率は $16.7 \%$ と低かった. 術式については 闻径ヘルニアを合併していたものが $13.3 \%$ あり, 鼠径 法で行うのが望ましいと考えられた．嵌頓後の手術は 緊急手術となり, 田中らが嵌頓症例18例中 2 例死亡と 報告している゙が，手術危険度も高く術後在院日数も 長くなるなど，患者の負担も重くなるので，日常診察

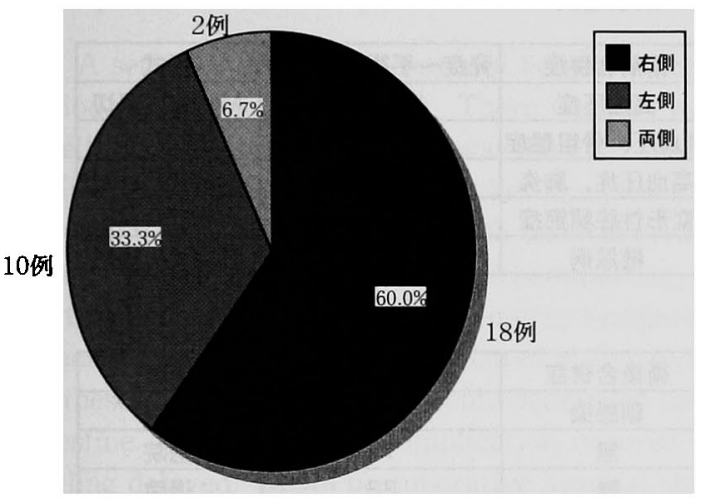

図 5 大腿へルニア症例部位
で注意を払うことで, 嵌頓前に診断・治療できるよう に努力すべきである。

大腿ヘルニアではヘルニア内容が還納されていて も，鼠径部の触診を注意深く行うことで還納されない 腹膜前脂肪織を腫瘤状に触知できることが多いので， 基本的な触診の重要性をあらためて強調したい.

\section{結 語}

大眼へルニアは高齢の女性に多く，日常診察で注意 を払うことによって嵌頓を防ぐ努力をすべきである.

表 1 大腿ヘルニア症例術前合併症

\begin{tabular}{|c|c|c|c|}
\hline & 非嵌頓例 $_{(\mathrm{n}=25)}$ & 嵌頓例 $(\mathrm{n}=5)$ & 計 \\
\hline 高血圧症 & 6 & 3 & 9 \\
\hline 糖尿病 & 3 & 1 & 4 \\
\hline 虚血性心疾思 & 1 & 0 & 1 \\
\hline 脳血管障害 & 1 & 0 & 1 \\
\hline 肺炎 & 1 & 1 & 2 \\
\hline 腸閉塞 & 0 & 4 & 4 \\
\hline 骨粗鬆症 & 6 & 1 & 7 \\
\hline 变形性関節症 & 2 & 1 & 3 \\
\hline 白内障 & 3 & 0 & 3 \\
\hline 鼠径ヘルニア & 2 & 0 & 2 \\
\hline
\end{tabular}

図 6 大腿ヘルニア症例手術術式 
表 2 大腿ヘルニア症例ヘルニア内容

\begin{tabular}{|c|c|c|}
\hline & 非嵌頓例 $_{(\mathrm{n}-26)}$ & 嵌頓例 $_{(\mathrm{n}-5)}$ \\
\hline 無し & 21 & 0 \\
\hline 大網 & 5 & 0 \\
\hline 小腸 & 0 & 4 \\
\hline 小腸十大網 & 0 & 1 \\
\hline
\end{tabular}

表 3 大腿ヘルニア症例術後合併症

\begin{tabular}{|c|c|c|c|}
\hline & 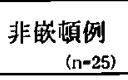 & 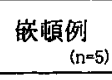 & $\bar{t}{ }_{(n-30)}$ \\
\hline 無 & 21 & 4 & 25 \\
\hline seroma & 2 & 0 & 2 \\
\hline 大腿腫脹 & 1 & 0 & 1 \\
\hline 創感染 & 0 & 1 & 1 \\
\hline 腰麻後頭痛 & 1 & 0 & 1 \\
\hline
\end{tabular}

表 4 大腿へルニア嵌頓症例

\begin{tabular}{|c|c|c|c|c|c|}
\hline & 主訴 & 部位 & 術前合併症 & 発症～手術時間(hr) & 術式 \\
\hline (1)80歳 & 腸閉塞症状+鼠径部膨隆 & 左 & 高血圧症 & 8 & $\mathrm{McVay}+$ 腸切 \\
\hline (2)79歳 女性 & 鼠径部㴧隆+疼痛 & 右 & 高血圧、骨粗筮症 & 24 & McVay \\
\hline (3) 92 歳 & 腸閉塞症状+鼠径部腿隆 & 右 & 高血圧症、肺炎 & 24 & McVay \\
\hline (4)77歳 & 腸閉塞症状+鼠径部膨隆 & 右 & 変形性凌関節症 & 24 & McVay \\
\hline (5)69歳 & 腸閉塞症状+ 鼠徍部膨隆 & 左 & 糖尿病 & 12 & $\mathrm{McVay}+$ 腸切 \\
\hline
\end{tabular}

\begin{tabular}{|c|c|c|c|c|c|}
\hline & ヘルニア内容 & 手術時间(min) & 術後合併症 & 術後在院日数 & 予後 \\
\hline (1) & 小腸 & 68 & 垥感染 & 42 & 退院 \\
\hline (2) & 小腸 & 74 & 無 & 14 & 退院 \\
\hline (3) & 小腸+大網 & 97 & 無 & 23 & 退院 \\
\hline (4) & 小腸 & 79 & 無 & 9 & 退院 \\
\hline (5) & 小腸 & 120 & 無 & 15 & 退院 \\
\hline
\end{tabular}

表 5 大腿ヘルニア症例手術時間, 術後在院日数

\begin{tabular}{|c|c|c|}
\hline & $\begin{array}{c}\text { 手術時間 (分) } \\
\text { (平均) }\end{array}$ & $\begin{array}{c}\text { 術後在院日数 } \\
\text { (平均) }\end{array}$ \\
\hline 非嵌頓例 & $\begin{array}{c}49 \sim 140 \\
(73.4)\end{array}$ & $\begin{array}{c}5 \sim 11 \\
(8.25)\end{array}$ \\
\hline 嵌頓例 & $\begin{array}{c}68 \sim 120 \\
(87.6)\end{array}$ & $\begin{array}{c}9 \sim 42 \\
(20.6)\end{array}$ \\
\hline
\end{tabular}




\section{文献}

1）棚瀬信太郎, 牧野永城：大駺へルニア. 出月康夫 他編、新外科学体系 腹壁・腹膜・イレウスの外 科, 中山書店, 東京, $1990, \mathrm{p} 92-105$

2）田中千凱, 伊藤隆夫, 大下裕夫：大跟へルニア嵌 頓によろ较扼性イレウス症例の検討. 腹部救急診 療の進歩 $12: 291-295,1992$

3）牧野永城, 西尾剛毅, 青木啓一他：高齢者大腿人 ルニア手術(McVay 手術). 手術 34：897-903, 1980
4）大谷五良：大眼ヘルニア．外科治療 $54: 431 一$ 439, 1986

5）数場庄一：大腿ヘルニア. 臨外 $43: 1071-1079$, 1988

6) Ponka JL, Brush BE : Problem of femoral hernia. Arch Surg $102: 417-423,1971$

7）三重野寛治：嵌頓ヘルニア. 臨外 $43: 1049$ 1055, 1988

8）冲永功太：大眼ヘルニア．外科診療 $35: 565 一$ 571,1993

\title{
STUDIES ON 30 CASES OF FEMORAL HERNIA
}

\author{
Kazuhiro YOSHII, Teruyuki SATO and Shigenori AKAGI \\ Department of Surgery, Kumihama Municipal Hospital
}

A series of 30 cases of femoral hernia which were operated on at the hospital in a recent 12-year period were clinically studied. There were 28 women and two men with a mean age of 73.2 years old. Swelling of the inguinal portion was the most common complain seen in 23 patients, followed by symptom of ileus in four patients and another symptoms in three patients. There were 18 patients with right femoral hernia, 10 patients with left femoral herunia and two patients with bilateral femoral hernia. All cases were diagnosed by physical examination. The diagnosis was made by palpation of the inguinal portion in the three patients with another symptoms and in the lateral lesion of two patients with bilateral femoral hernia. Incarceration occured in five patients (16.7\%) who underwent an emergency operations. Of these five patients, two patients demanded resection of the intestine because of necrosis of the small intestine. Post operative complication occured in one out of the two resected patients whose wound healing delayed. Mean postoperative hospital stay in the incarcerated cases was longer than that in the non-incarcerated cases. We should make efforts to prevent the patients who are often elderly women from incarcerating of the hernia by careful routine medical examinations. 